\title{
EFFECTS OF CIMETIDINE ON BROILER FATTENING AND ON STRESS-INDUCED GIZZARD EROSION IN CHICKEN
}

\author{
Ž. Grabarević*, P. DŽaja, J. Perić, V. ŠERman, Z. BiĐin, H. MAZIJA, N. Mas, \\ Ž. MiKULEC, K. ČULJAK, Z. ŠIMEC and B. NJARI \\ Faculty of Veterinary Medicine, University of Zagreb, 10000 Zagreb, Heinzelova 55, \\ Republic of Croatia
}

(Received March 24, 1998; accepted October 13, 1998)

\begin{abstract}
The work describes the effects of cimetidine on stress-induced gizzard erosions (Experiment A) and the influence of the long-term application (42 days) of the same drug on weight gain and feed consumption during broiler fattening (Experiment B). For Experiment A, 60 male, three-day-old chicks were divided into two groups: $\mathrm{C}(\mathrm{n}=30)$ - control chicks treated with $0.5 \mathrm{ml}$ saline; $\mathrm{CIM}(\mathrm{n}=$ 30 ) - chicks treated with cimetidine in a dose of $5 \mathrm{mg} / \mathrm{kg}$ body weight (b. w.) intragastrically. All chicks were stressed using a modified water-immersion stress method according to which the chicks, after $24 \mathrm{~h}$ of feed deprivation, were immersed in tap water $\left(17^{\circ} \mathrm{C}\right)$ for a few seconds. Under chloroform anaesthesia ten chicks from each group were killed 1, 2 and $3 \mathrm{~h}$ after the stressing. The morphometric analysis of gizzard erosion (GE) and histopathological examinations of gizzards were performed for each chick. In Experiment B, 32 one-day-old broilers of both sexes were used. The control group was untreated $(n=16)$ while the CIM group $(\mathrm{n}=16)$ was fed the same diet supplemented with $10 \mathrm{mg}$ of cimetidine per kilogram of feed throughout the fattening period (42 days). The results of Experiment A showed decreased mean length of the GE in the cimetidine-treated birds as compared with the GE lesions of the controls. In Experiment B, the treated chicks had reduced liveweight $(1835.1 \mathrm{~g})$, carcass weight $(1474.6 \mathrm{~g})$ and increased feed consumption (2115 g of feed per kilogram of weight gain) compared to the controls in which the same parameters were $1898.5 \mathrm{~g}, 1574.2 \mathrm{~g}$ and $1797 \mathrm{~g}$, respectively. The results show that while stress-induced GE of chicks can be medicated pharmacologically, long-term application of the same substance impairs the results of fattening.
\end{abstract}

Key words: Cimetidine, stress, broiler chickens, fattening

Gizzard erosion (GE) is a very considerable problem in poultry production all over the world (Johnson and Pinedo, 1971; Masumura et al., 1981; Kán-

\footnotetext{
*Address for correspondence: Prof. Dr. Željko Grabarević, Department of Pathology, Faculty of Veterinary Medicine, University of Zagreb, 10000 Zagreb, Heinzelova 55, Croatia; E-mail: zgrabar@vef.hr; Fax: +385 1214697
} 
tás and Dobos-Kovács, 1990; Sharma and Pandey, 1990; Grabarević et al., 1993). Although it seems that the principal aetiological factors are gizzerosine (Okazaki et al., 1983) and stress (Grabarević et al., 1993), there are few investigations on medical prevention or therapy of GE. Several substances, such as vitamin $\mathrm{E}$ (Janssen and Germs, 1973), the $\mathrm{H}_{2}$ antagonist cimetidine (Masumura et al., 1985; Sugahara et al., 1988), stomach antacids (Miyazaki and Umemura, 1987) and omeprazole (Hinrichsen et al., 1997), were found to be gastroprotective, although, concerning cimetidine, there are some studies indicating that it may increase mortality rate in affected chicks (Barrera et al., 1991). Besides that, cimetidine is of particular interest because of its intriguing influence not only on gastric juice secretion, but also on inflammation and immunomodulation. Namely, there are interesting new data that demonstrate the immunostimulant effect of cimetidine (Ershler, 1990). It should also be noted that histamine represents the link between stress-induced (Grabarević et al., 1993; Džaja et al., 1995; Džaja et al., 1996) and gizzerosine-induced GE (Masumura et al., 1985). However, there are no data that describe the effects of $\mathrm{H}_{2}$ antagonists on stressinduced GE and their possible role in the prevention of this disease.

Thus, the aim of this study was to investigate the effects of cimetidine $\left(\mathrm{H}_{2}\right.$ antagonist) on stress-induced GE and its influence on broiler growth and feed conversion during fattening.

\section{Materials and methods}

Birds

A total of 92 one-day-old chicks were used in all experimental groups: male Isa Brown chicks in Experiment A and Hybro broiler chicks of both sexes in Experiment B. The chicks were kept in cages under constant artificial light, adequate temperature and relative humidity $(65 \%)$. Feed and water were provided ad libitum.

\section{Design of experiment}

Experiment $A$. Chicks were divided into two groups: C (30 birds) - control chicks treated with $0.5 \mathrm{ml}$ of saline; CIM (30 birds) - chicks treated with cimetidine (Sigma Chemical Company, St. Louis, USA) in a dose of $5 \mathrm{mg} / \mathrm{kg}$ body weight (b. w.).

After a period of adaptation to the new environment (first three days), the test substances were applied directly into the crop via a plastic tube one hour before stressing. All chicks were stressed according to a previously described method (Grabarević et al., 1993; Džaja et al., 1995). This method is a modified water-immersion stress according to which the chicks, after $24 \mathrm{~h}$ of feed depri- 
vation, were immersed in tap water $\left(17^{\circ} \mathrm{C}\right)$ for a few seconds. Ten chicks from each group were killed under chloroform anaesthesia 1, 2 and $3 \mathrm{~h}$ after stressing. The gizzards were opened along the great curvature and rinsed in tap water. Every visible lesion was transcribed onto transparent plastic foil and measured through millimetre paper. The severity of GE was expressed as the sum of lengths of lesions (mm). For histopathological examination, gizzard samples were fixed in $10 \%$ buffered formalin, embedded in paraffin, sectioned $5 \mu \mathrm{m}$ thick and, after deparaffinisation, stained with haematoxylin-eosin.

Experiment B. The chickens were divided in two groups: $\mathrm{C}(\mathrm{n}=16)-$ control birds which were fed diets adequate for broiler fattening (starter, finisher I, finisher II; manufacturer Agrokoka Hrvatski Leskovac, Croatia), which passed the required chemical and bacteriological tests; CIM $(n=16)$ - chickens were fed the same feed as the controls but with $10 \mathrm{mg}$ cimetidine added per kilogram of feed.

During fattening (42 days), individual chick weights were recorded weekly and feed consumption was measured. At the end of the fattening period, chicks were killed by bleeding under chloroform anaesthesia and the sex, body weight and carcass weight of each chick were recorded. Also, the organ indices for heart, liver, proventriculus, spleen and bursa of Fabricius were calculated as described previously (organ weight/body weight $\times 1000$; Dohms and Metz, 1991).

\section{Statistical analysis}

Gizzard lesions between different groups and organ indices were analysed with Kruskall-Wallis ANOVA followed by the Mann-Whitney U test. Statistical analysis of the body and carcass weights was performed by Student's $t$-test. Differences were considered to be significant when the $\mathrm{P}$ value was lower than or equal to 0.05 .

\section{Results}

\section{Experiment $A$}

The mean lengths of the GE are shown in Fig. 1. It is very obvious that the cimetidine-treated group of chicks had much smaller lesions compared to the controls (CIM: 2.6, 3.8, $2.1 \mathrm{~mm}$; C: 3.3, 5.9, $3.4 \mathrm{~mm}$ ). However, a marked difference was demonstrable only in the groups killed $2 \mathrm{~h}$ after stressing. Histopathologically the lesions varied from mild changes (Fig. 2) characterised by vacuolisation and discoloration of the cuticle to severe ulcers (Fig. 3) in which deep haemorrhagic lesions affecting even the gizzard muscular layer were noticed. 


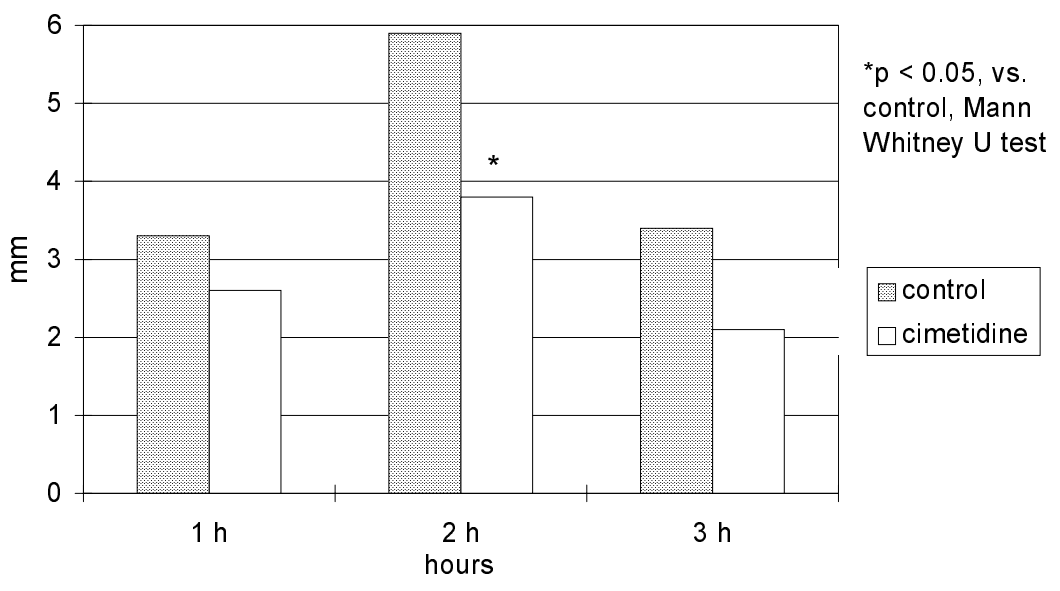

Fig. 1. Length (mm) of the gizzard erosion in stressed chicks

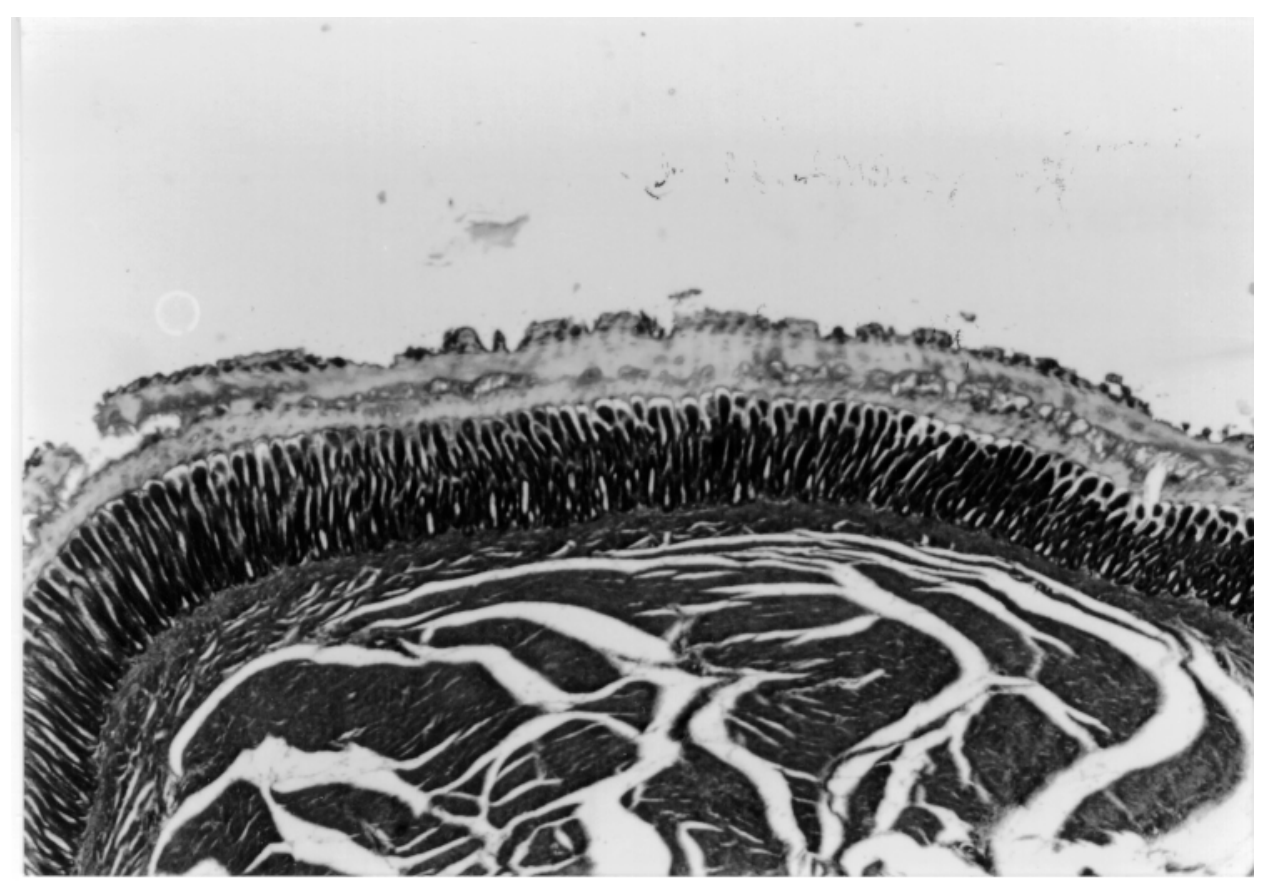

Fig. 2. Experiment A, control (1 h). Discoloration, vacuolisation and erosion of the gizzard lining. Haematoxylin and eosin (HE), $\times 10$ 


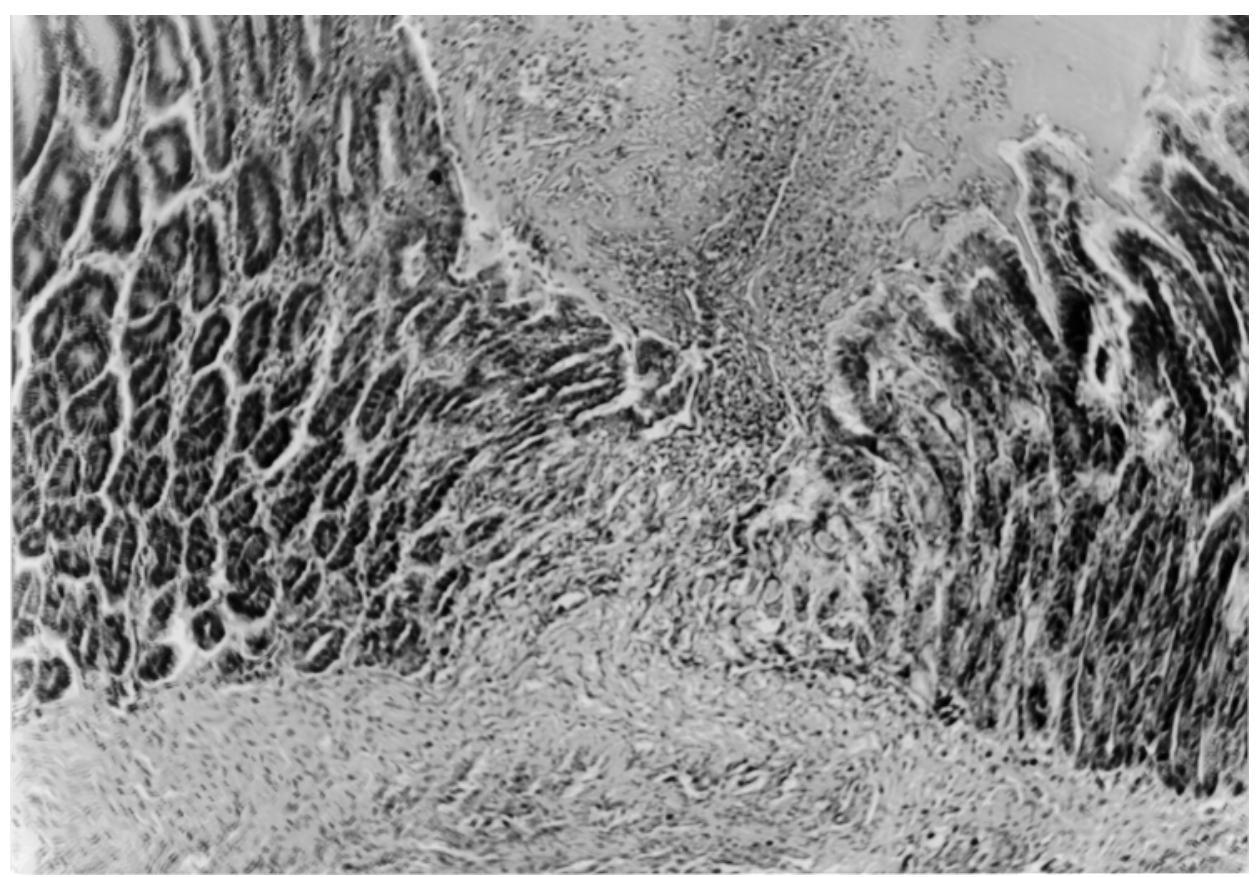

Fig. 3. Experiment A, control ( 3 h). Fully developed haemorrhagic gizzard ulcer. HE, $\times 40$

\section{Experiment $B$}

It is clear from Fig. 4 that cimetidine-treated chickens continuously showed a significantly smaller body weight gain than the control birds. Analysis of body and carcass weights (Fig. 5) showed a striking influence of cimetidine on female broilers [Body weight $(\mathrm{g})$ : C: (mean \pm SD) $1814.2 \pm 102.109$; CIM: $1679.7 \pm 148.452$. Carcass weight $(\mathrm{g}): \mathrm{C}: 1547.2 \pm 146.669$; CIM: $1344.2 \pm$ 130.604], while male birds did not seem to be affected by cimetidine application at all. Statistical analysis of the organ indices revealed a significant increase only in the index of the bursa of Fabricius (Fig. 6) in the cimetidine-treated birds (C: $2.8 \pm 0.595$; CIM: $3.7 \pm 0.651$ ). Although the other indices were also smaller in the CIM group, the difference did not reach the level of significance.

The mean value of feed conversion ( $\mathrm{kg}$ of feed per $\mathrm{kg}$ of weight gain) was $1797 \mathrm{~g}$ in the control and $2115 \mathrm{~g}$ in the cimetidine-treated broilers. 


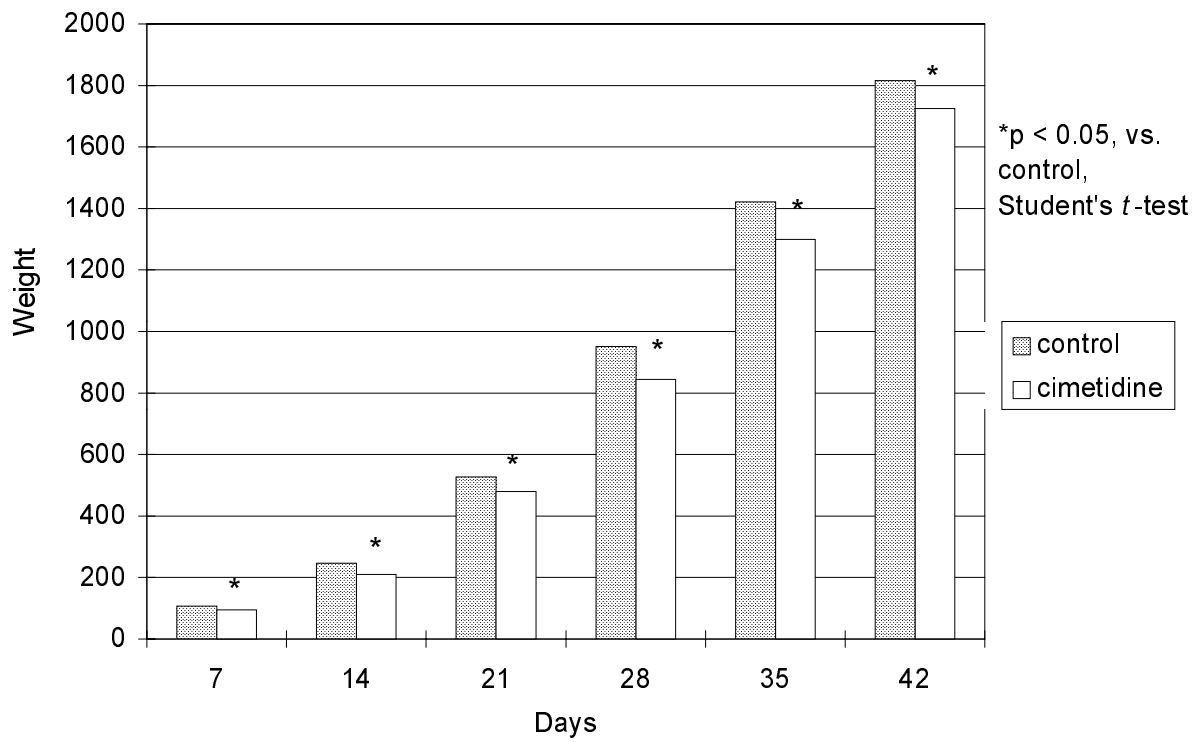

Fig. 4. Mean body weights of the groups of chickens used in the experiment ( $\mathrm{g}$ )

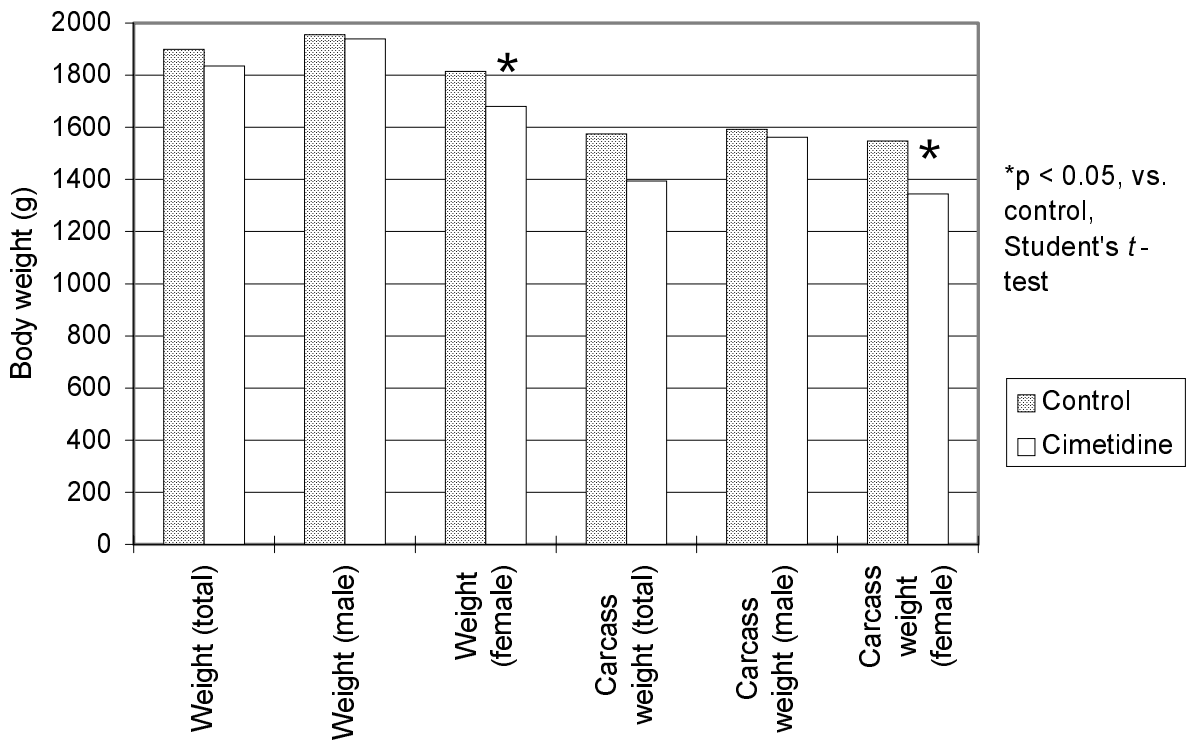

Fig. 5. Mean weights (g) of the control and the cimetidine-treated chickens 
Fig. 6. Mean organ indices of the control and cimetidine-treated chickens

\section{Discussion}

The effect of stress in inducing gastric ulcers is well known (Paré and Glavin, 1986). The same is true concerning the positive effects of $\mathrm{H}_{2}$ antagonists in minimising and preventing stress-induced stomach lesions (Adams, 1992). So far, these data have not been confirmed in birds, although there are many papers that describe the effects of cimetidine on gizzerosine-induced GE (Masumura et al., 1985; Sugahara et al., 1988; Barrera et al., 1991; Horikawa et al., 1992). If histamine represents the mutual biomediator that provokes ulcers in both cases (Džaja et al., 1995), our finding is consistent with those investigations. It must be pointed out that gastric juice by itself, and some biomediators and hormones that increase its secretion, such as gizzerosine (Grabarević et al., 1998) and gastrin (Dodig et al., 1993), are not ulcerogenic in some cases. The histopathological changes and severity of GE described in this paper are very similar to those described in the previous papers (Grabarević et al., 1993; Džaja et al., 1996).

The analysis of broiler fattening showed a significant and continuous decrease of body weights (Fig. 4) and increased feed consumption in the cimetidine-treated chicks throughout the 7-week trial. This could be readily explained by maldigestion which probably resulted from the decreased secretion of gastric juice induced by cimetidine. It is more difficult to explain the finding that cimetidine exerted a negative influence predominantly on female chicks (Fig. 5). It should be emphasised that earlier an opposite finding had been described for 
histamine. Namely, in that work (Džaja et al., 1996) the authors found that the application of histamine resulted in significantly decreased weights only in male chickens. The oestrogen-like effect of cimetidine is well known because it acts both as an androgen receptor antagonist and as a testosterone biosynthesis inhibitor (Cook et al., 1997), although on that basis one should expect that males rather than females represent the main targets of cimetidine action. From these results it appears that androgen receptors and/or testosterone play a very important role in the weight gain of broilers. Histamine- and cimetidine-induced weight decrease in males and females, respectively, probably occurs through different pathophysiological mechanisms.

The finding that the mean organ index of the bursa of Fabricius is significantly increased in the cimetidine-treated chicks is completely consistent with data of the literature that describe the important immunostimulant and immunomodulatory effects of this drug (Beer and Rocklin, 1990; Beer et al., 1990).

\section{Acknowledgement}

This work was partially sponsored by grant 053019 from the Ministry of Science of the Republic of Croatia.

\section{References}

Adams, H. R. (1992): Histamine and antihistamines; Serotonin and antiserotonines. In: Booth, N. R. and McDonald, L. E. (eds) Veterinary Pharmacology and Therapeutics. Iowa State University Press, Ames, pp. 441-451.

Barrera, E. M., Gonzales, E. A. and Caballero, E. F. (1991): Effect of cimetidine addition on broiler chickens fed a toxic fish meal diet causing black vomit (in Spanish, with English abstract). Vet. Mex. 22, 143-149.

Beer, D. J. and Rocklin, R. E. (1990): Histamine-induced suppressor cell systems in guinea pigs and humans. In: Rocklin, R. E. (ed.) Histamine and $\mathrm{H}_{2}$ Antagonists in Inflammation and Immunodeficiency. Marcel Dekker, Inc., New York-Basel, pp. 39-64.

Beer, D. J., Cruikshank, W. W., Berman, J. S., Bernardo, J., Theodore, A. C. and Center, D. M. (1990): Histamine-induced human lymphocyte chemoattractant lymphokines: Mechanisms for the amplification of cell-mediated immune responses. In: Rocklin, R. E. (ed.) Histamine and $\mathrm{H}_{2}$ Antagonists in Inflammation and Immunodeficiency. Marcel Dekker, Inc., New York-Basel, pp. 81-106.

Cook, J. C., Frame, S. R. and Obourn, J. D. (1997): Leydig cell tumours. In: Sipes, G., McQueen, C. A. and Gandolfi, A. J. (eds) Comprehensive Toxicology, Vol. 10. Pergamon-Elsevier Science Ltd., Cambridge University Press, Cambridge, pp. 193-201.

Dodig, M., Rotkvić, I., Grabarević, Ž., Sikirić, P., Drahotusky, T., Erceg, D., Đačić, S. and Seiwerth, S. (1993): Pentagastrin cytoprotection in ethanol-induced gastric mucosal lesions in rats. J. Vet. Med. A 40, 509-515. 
Dohms, J. E. and Metz, A. (1991): Stress - mechanisms of immunosuppression. Vet. Immunol. Immunopathol. 30, 80-109.

Džaja, P., Grabarević, Ž., Perić, J., Artuković, B., Tišljar, M., Mrljak, V. and Šoštarić, E. (1995): Effects of histamine on gizzard erosions and on the activity of selected enzymes in chickens. Acta Vet. Hung. 43, 431-441.

Džaja, P., Grabarević, Ž., Perić, J., Mazija, H., Prukner-Radovčić, E., Bratulić, M., Žubčić, D. and Ragland, W. L. III (1996): Effects of histamine application and water-immersion stress on gizzard erosion and fattening of broiler chicks. Avian Pathol. 25, 359-367.

Ershler, W. B. (1990): In vivo effects of cimetidine in mice. In: Rocklin, R. E. (ed.) Histamine and $\mathrm{H}_{2}$ Antagonists in Inflammation and Immunodeficiency. Marcel Dekker, Inc., New YorkBasel, pp. 191-204.

Grabarević, Ž., Tišljar, M., Džaja, P., Artuković, B., Seiwert, S. and Sikirić, P. (1993): Stress induced gizzard erosion in chicks. I. Gross and histopathological findings. J. Vet. Med. A 40, $265-270$.

Grabarević, Ž., Džaja, P., Mrljak, V. and Artuković, B. (1998): The effects of gizzerosine on laying hens. Praxis vet. 46, 35-41.

Hinrichsen, J. P., Neira, M., Lopez, C., Chiong, M., Ocaranza, M. P., Gallardo, R., Rutman, M., Blamey, J. and Lavandero, S. (1997): Omeprazole, a specific gastric secretion inhibitor on oxynticopeptic cells, reduces gizzard erosion in broiler chicks fed with toxic fish meals. Comp. Biochem. \& Physiol. C, Pharmacol., Toxicol. \& Endocrinol. 117, 267-273.

Horikawa, H., Masumura, T., Hirano, S., Watanabe, E. and Ishibashi, T. (1992): Optimum dietary level of gizzerosine for maximum calcium content in the femur of chicks. Jpn. Poult. Sci. 29, 361-367.

Janssen, W. M. and Germs, A. C. (1973): Gizzard erosion, meat flavor and vitamin E in broilers. Acta Agr. Scand. (Suppl.) 19, 72-78.

Johnson, D. C. and Pinedo, D. C. (1971): Gizzard erosion and ulceration in Peru broilers. Avian Dis. 15, 835-837.

Kántás, K. and Dobos-Kovács, M. (1990): Ulcerative gizzard disease in broilers and laying hens (in Hungarian, with English abstract). Magyar Állatorvosok Lapja 45, 93-97.

Masumura, T., Horaguchi, H., Horikawa, H. and Sugahara, M. (1981): Gizzard erosion and ulceration in broilers. Toxic substances in fish meal. Jpn. Poult. Sci. 18, 98-104.

Masumura, T., Sugahara, M., Noguchi, T., Mori, K. and Naito, H. (1985): The effect of gizzerosine, a recently discovered compound in overheated fish meal, on gastric acid secretion in chicken. Poultry Sci. 64, 365-361.

Miyazaki, S. and Umemura, Y. (1987): Effects of histamine antagonists, anticholinergic agent and antacid on gizzard erosion in broiler chicks. Br. Poult. Sci. 28, 39-45.

Okazaki, T., Noguchi, T., Igarachi, K., Sakagami, Y., Seto, H., Mori, K., Naito, H., Masumura, T. and Sugahara, M. (1983): Gizzerosine, a new toxic substance in fish meal causes severe gizzard erosion in chicks. Agric. Biol. Chem. 47, 2949-2952.

Paré, W. P. and Glavin, G. B. (1986): Restraint stress in biomedical research. A Review. Neurosci. \& Biobehav. Rev. 10, 339-370.

Sharma, R. N. and Pandey, G. S. (1990): An outbreak of gizzard erosion and ulceration in chick in Zambia. Vet. Bull. 1991, No. 8552.

Sugahara, M., Hattori, T. and Nakajima, T. (1988): Suppression effect of cimetidine, sodiumbicarbonate and magnesium-trisilicate for gizzard erosion in broiler chicks. Jpn. J. Zootechn. Sci. 59, 306-310. 